University of Rhode Island

DigitalCommons@URI

Open Access Master's Theses

1986

\title{
Growth and Development Issues in a Small Town
}

Elaine Lazarus Toplyn

University of Rhode Island

Follow this and additional works at: https://digitalcommons.uri.edu/theses

\section{Recommended Citation}

Toplyn, Elaine Lazarus, "Growth and Development Issues in a Small Town" (1986). Open Access Master's Theses. Paper 688.

https://digitalcommons.uri.edu/theses/688

This Thesis is brought to you for free and open access by DigitalCommons@URI. It has been accepted for inclusion in Open Access Master's Theses by an authorized administrator of DigitalCommons@URI. For more information, please contact digitalcommons-group@uri.edu. 
GROWTH AND DEVELOPMENT ISSUES

IN A SMALL TOWN

BY

ELAINE LAZARUS TOPLYN

A RESEARCH PROJECT SUBMITTED IN

PARTIAL FULFILLMENT OF THE REQUIREMENTS

FOR THE DEGREE OF MASTER OF

COMMUNITY PLANNING

UNIVERSITY OF RHODE ISLAND

1986 
MASTER OF COMMUNITY PLANNING

RESEARCH PROJECT

$\mathrm{OF}$

ELAINE LAZARUS TOPLYN

Approved:

Major Professor $\frac{1 \text { a t. Fon }}{\text { Howard H. Foster }}$

Acknowledged:

Director

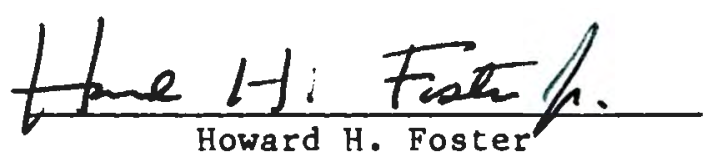




\section{ABSTRACT}

The town of Raynham, Massachusetts, is a small community trying to cope with growth and development. As a member of the Planning Board for one year, I examined the methods and tools used to deal with the major issues raised and discussed in this paper. Recommendations as to restructuring governmental organization and zoning methodology are discussed. 
Page

Transportation to Work

Population

Occupation by County

Occupation by Percent of Residents

Commuting Patterns

Transportation to Work
Table I

Table II

Table IIIa

Table IIIb

Table IV

Table V
6

8

10

11

12

13 
Page

Major Roadway Network

Map 1

3

Southeastern Massachusetts

Map 2

9

Zoning

Map 3

17

Cedar Ridge Estates

Map 4

26

Raynham's Golden Mile

Map 5

39 


\section{Page}

Introduction 1

Chapter 1
A. A Profile of Raynham
B. Growth in Southeastern Massachusetts 7
$\begin{array}{ll}\text { C. Form of Government } & 14\end{array}$
D. Zoning

Chapter 2
A. Low Income Housing
B. Cedar Ridge Estates
C. Mobile Home Parks

Chapter 3

Analys is

Chapter 4

Recommendations and Conclusion 


\section{INTRODUCTION}

This thesis research project revolves around my thirteen month tenure as a member of the Planning Board in Raynham, Massachusetts. After completing graduate courses at the University of Rhode Island, I moved back to my home town and filled a vacancy on the Board. It was an opportunity to see town government in action and to be a participant. Planning knowledge was helpful, but the many laws, rules, and regulations governing the Board's actions were new. It was the introduction into the world of small town government that was particularly intriguing.

The reality of the situation in Raynham was evident immediately. The smal1 town of about 6,000 people that I had grown up in was now over 9,000 and the increased commercial and housing development that accompanied the growth was evident. Raynham had always been a town of first-time home buyers and young families, and this is still the case. It remains suburban in nature but is facing issues typical of any growing community. Some of the problems are compounded by environmental constraints and others by inefficient government. The study of these issues and the methods that the town used to deal with them are presented here.

Three case studies are examined which illustrate the types of issues raised. Major issues discussed are low and moderate income housing, zoning, and environmental protection. The analysis and recommendations will be applicable to any small town experiencing similar problems. These issues have presented a new set of problems for this town with little growth management experience. 


\section{CHAPTER 1}

\section{A. A Profile of Raynham}

Raynham is a rapidly growing town located at the crossroads of southeastern Massachusetts, eighteen miles east of Providence, Rhode Island, thirty miles south of Boston, and twenty miles from Cape Cod. People traveling through Raynham are usually on the way to one of these three places on the three major highways passing through town, State Routes 24 and 25 and Interstate Route 495. The longest stretch is that of Route 24, which travels three and a half miles through Raynham (See Map 1). Routes 24 and 495 have exits which feed directly into the town, Route 495 onto Broadway (Route 138) and Route 24 onto Route 44 , the main commercial strip in the southern end of town.

The town is an attractive place for commuters to live, due to the location of highways. As a result of this, population has risen from 2,426 in 1950 to 9,085 in 1980 , a $274 \%$ increase. This population increase is the largest in southeastern Massachusetts and in Bristol County, where Raynham is located, the population grew $24 \%$ during this period. Along with the population increase, the number of housing units has risen comparably. From 1970 to 1980 , the numer of units rose $56 \%$, averaging 100 units per year. This growth is phenomenal given the environmental constraints that Raynham has.

A large percent of town acreage is unsuitable for development, either due to poor soil quality or wetlands. In fact, $32 \%$ of the town is wetlands, the topography of Raynham being generally flat with gentle slopes and an abundance of small ponds and swamps. Despite poor soil conditions, there is only one 


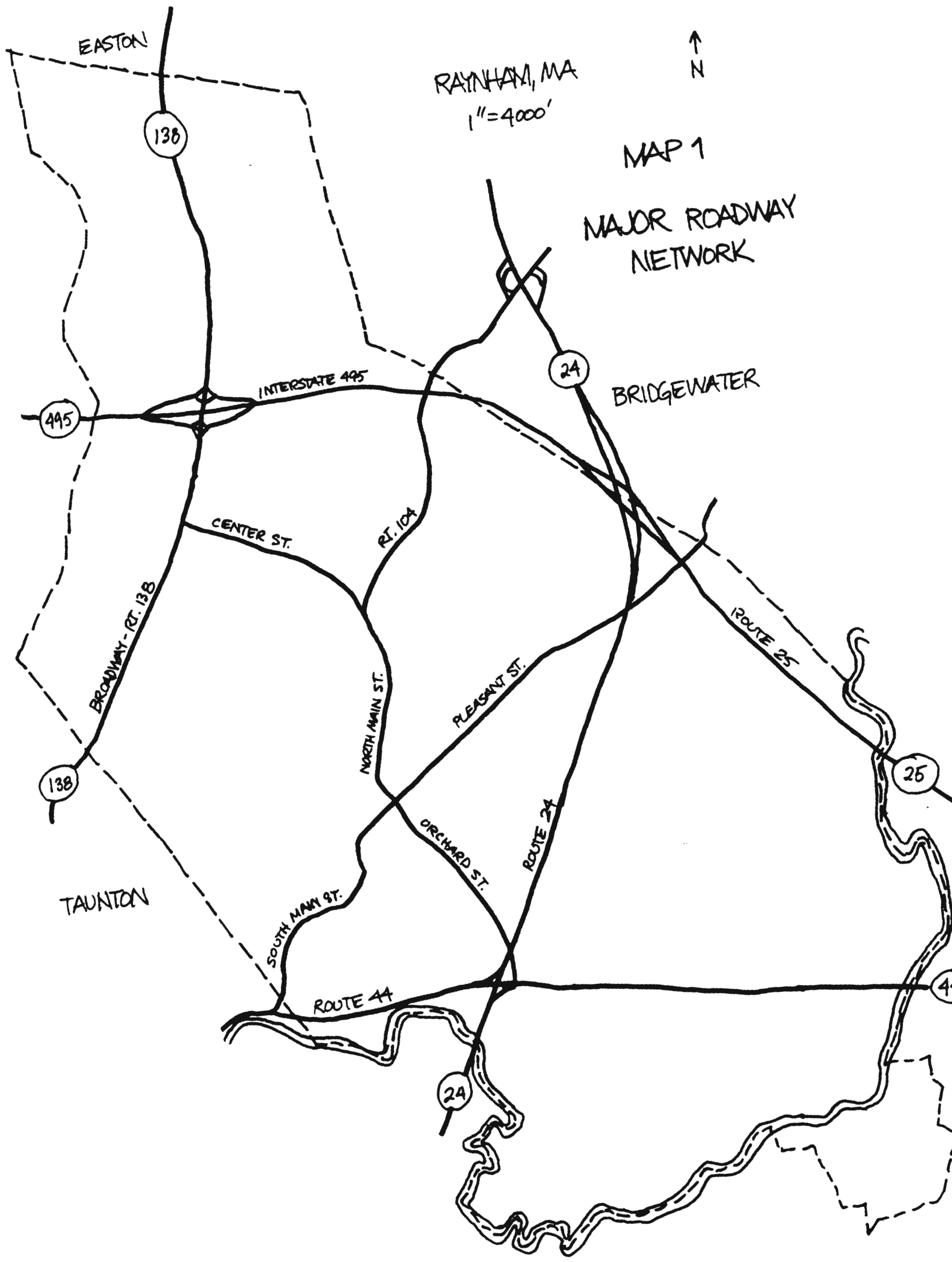


area of town with sewers, the commercial corridor along Route 44. In addition, $76 \%$ of town residents receive public water through two districts, with the remainder of residents relying on private wells. Town water is obtained through underground wells.

Raynham residents are mainly professional white collar workers, with a relatively high level of education and moderate income (U.S. Census). Many residents moved to town because of its excellent school system and low land prices. According to the 1980 U.S. Census, the median value of homes in 1980 was $\$ 45,000$, which is relatively low compared with state figures for the same year. Today, most homes in Raynham sell for $\$ 120,000$ up to $\$ 165,000$ according to Caldwell Banker Real Estate of Taunton. They also indicated that home prices have risen $300 \%$ since 1980 and their market studies further indicate that prices will rise another $100 \%$ to $200 \%$ in the next 36 months.(1) Along with a low property tax rate, the affordable housing (for Massachusetts) and rural character makes Raynham an attractive community in which to live. Home prices are rising fast out of the moderate income range.

Although Raynham has a reputation of being a quiet rural community, it has been losing much of its forest land, agricultural or open land and wetlands to encroaching development. According to the Southeastern Regional Planning and Economic Development District (SRPEDD), in 1950 the town had 2,000 acres of agricultural land, and in 1980, this figure had dropped to approximately 650 acres. There have been increases in urban land uses, especially public and quasi-public open space, commercial, and industrial uses since 1971. These trends are common for many communities who have experienced growth in recent years. 
Raynham operates with a budget surplus, $64.5 \%$ of its revenues coming from property taxes. Residents, typical of most people, would like to see property taxes lowered, and they feel some animosity toward the School Department and Police Department, who receive the bulk of town expenditures.

In past years, the School Department received whatever amount it requested in its budget, and there was little the town could change. However, a recent state law allows towns to scrutinize more closely and change items in the school budget. The Superintendent of Schools has traditionally been a powerful figure in town, and tensions may even increase over budget battles. Peak school enrollment occurred in 1976-77 at 2,286 elementary and junior high school students attending five schools. High school students attend either the Bristol-Plymouth Regional Technical High School in Taunton or the Bridgewater-Raynham Regional High School in Bridgewater. The town pays a variable amount to each school district.

Along with the major highway networks through town, other transportation elements include bus service. Two bus routes pass through the town. The first route travels along Route 138 from Taunton to Boston several times daily, providing commuter service and service to Raynham Park, the greyhound racing track. The second 1 ine operates along Route 44 from Taunton to Middleboro (and Plymouth during the summer) and makes one stop in Raynham. The Greater Atcleboro-Taunton Regional Transit Authority (GATRA) operates local bus service in Taunton, and Raynham is eligible to join at any time. However, there has not been sufficient interest, partially due to the fact that the majority of residents own two automobiles.(2) 
Most residents drive to work, and eleven percent carpool. According to SRPEDD, major employment centers for Raynham residents are (1981):(3)

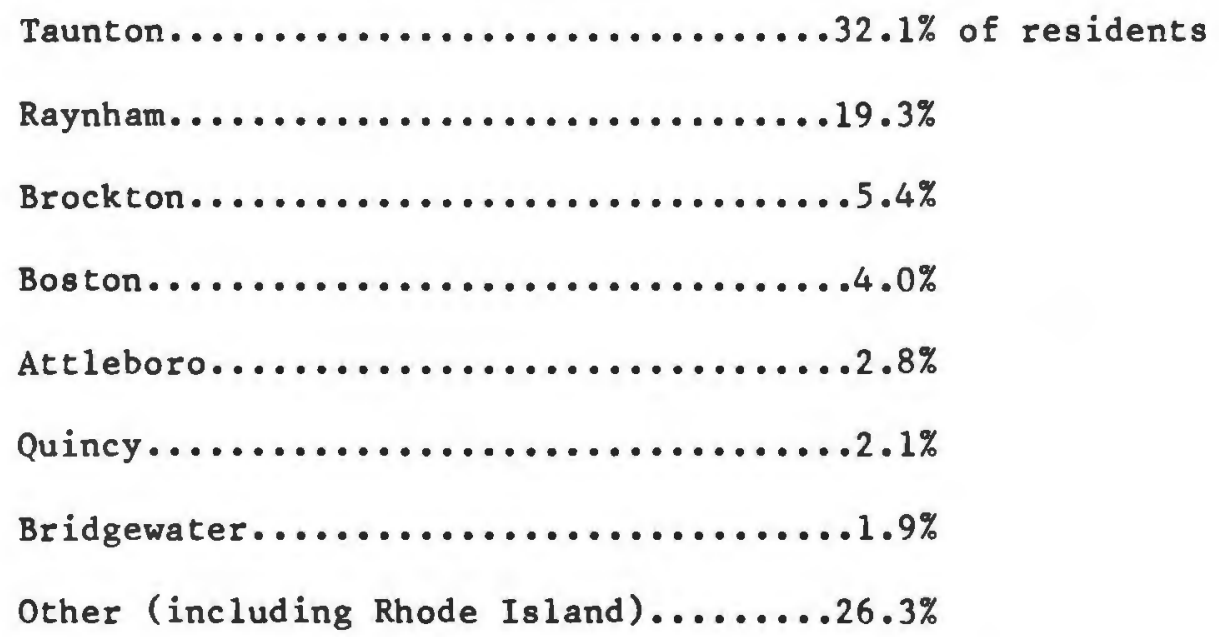

These figures indicate that most residents are employed locally, despite the convenience of major highways. However, although Route 24 has provided access to Fall River and Boston for at least 25 years, the Route 24 and 495 intersection was only completed in 1982. Methods of transportation to work is likely to remain the same in the future. According to the $1980 \mathrm{U} . \mathrm{S}$. Census, the following table shows modes of transportation to work.

$\underline{\text { Table I }}$

Transportation to Work

\begin{tabular}{lrc} 
Mode of Transportation & Number & Percent \\
\cline { 2 - 3 } Private Vehicle & 4,063 & $95.9 \%$ \\
Drive Alone & 3,362 & $82.7 \%$ \\
Carpool & 701 & $17.3 \%$ \\
Public Transportation & 55 & $1.3 \%$ \\
Walked Only & 66 & $1.6 \%$ \\
Other Means & 21 & $.5 \%$ \\
Worked at Home & 31 & $.7 \%$
\end{tabular}


Raynham, throughout its history, has been a rural, quiet community. However, this is changing, and the town is in a transition period which began in the 1960 's. At this time, growth of housing and business began to impact on the environment and the image of the town. The problems have largely gone unsolved and have compounded in the ensuing years. Raynham is not alone as the population growth in the town is a regional phenomenon.

\section{B. Growth in Southeastern Massachusetts}

Growth in southeastern Massachusetts has been in evidence since at least 1960. As an area outside the Boston metropolitan area with a relatively high amount of available land, it has become more desirable to industry and home buyers. Not only is there the quantity of undeveloped land, but its prices are low compared with other outlying areas of Boston.

For the purposes of this analysis, Southeastern Massachusetts will be geographically defined as Bristol and Plymouth Counties combined, as each comprises approximately half of the southeastern area (See Map 2). Taken separately, their characters are different. Bristol County includes the economically depressed urban areas of New Bedford and Fall River, and is more industrial in character. Plymouth County includes more white collar bedroom communities. Neither one by itself is a good representation of the area as a whole, so they will be combined to give a more accurate picture of past and current conditions. Raynham is located on the border between the two in Bristol County.

Population growth since 1960 is shown below in Table II. 
Table II

Population

\begin{tabular}{|c|c|c|c|c|c|}
\hline & 1960 & 1970 & 1980 & $\%$ Change $60-70$ & $\%$ Change $70-80$ \\
\hline Bristol & 398,488 & 444,301 & 474,671 & $11 \%$ & $7 \%$ \\
\hline Plymouth & 248,449 & 333,314 & 405,437 & $34 \%$ & $22 \%$ \\
\hline
\end{tabular}

Between 1960 and 1970, Plymouth County was the second fastest growing county in Massachusetts, after neighboring Barnstable County on Cape Cod. Bristol County was seventh in its growth rate among the fourteen counties, and both had growth rates higher than the state average of $10.5 \%$. From 1970 to 1980, the two counties continued to grow, although at slower rates. Plymouth County was still the second fastest growing county, and Bristol was still seventh. The state's population grew $1 \%$ during the same period. The slowest growing county from 1960 to 1980 was Suffolk, or the city of Boston. In fact, the majority of the slowest growing counties, including Suffolk County, which lost population during both periods, are clustered around Boston to the north and west. These traditional suburban areas are now encountering urban problems such as overcrowding, increased crime rates and aging housing stock in addition to high real estate prices. The fastest growing counties are located south, north and west of Boston, outside older metropolitan areas.

According to the 1980 U.S. Census, $16.9 \%$ of Bristol County's year-round housing units were built between 1970 and $1980,32.4 \%$ between 1940 and 1970 , and $50.7 \%$ built 1939 or earlier. In Plymouth County, the housing stock is newer, with $23.7 \%$ built between 1970 and 1980 , and $36.8 \%$ built in 1939 or earlier. Homeowner vacancy rates in 1980 were $.8 \%$ and $1.1 \%$ in Bristol and Plymouth Counties respectively. Rental vacancy rates were $5.3 \%$ and $5.4 \%$ respectively. These vacancy rates are relatively low, which indicates a 


\section{SOUTHEASTERN MASSACHUSETTS}

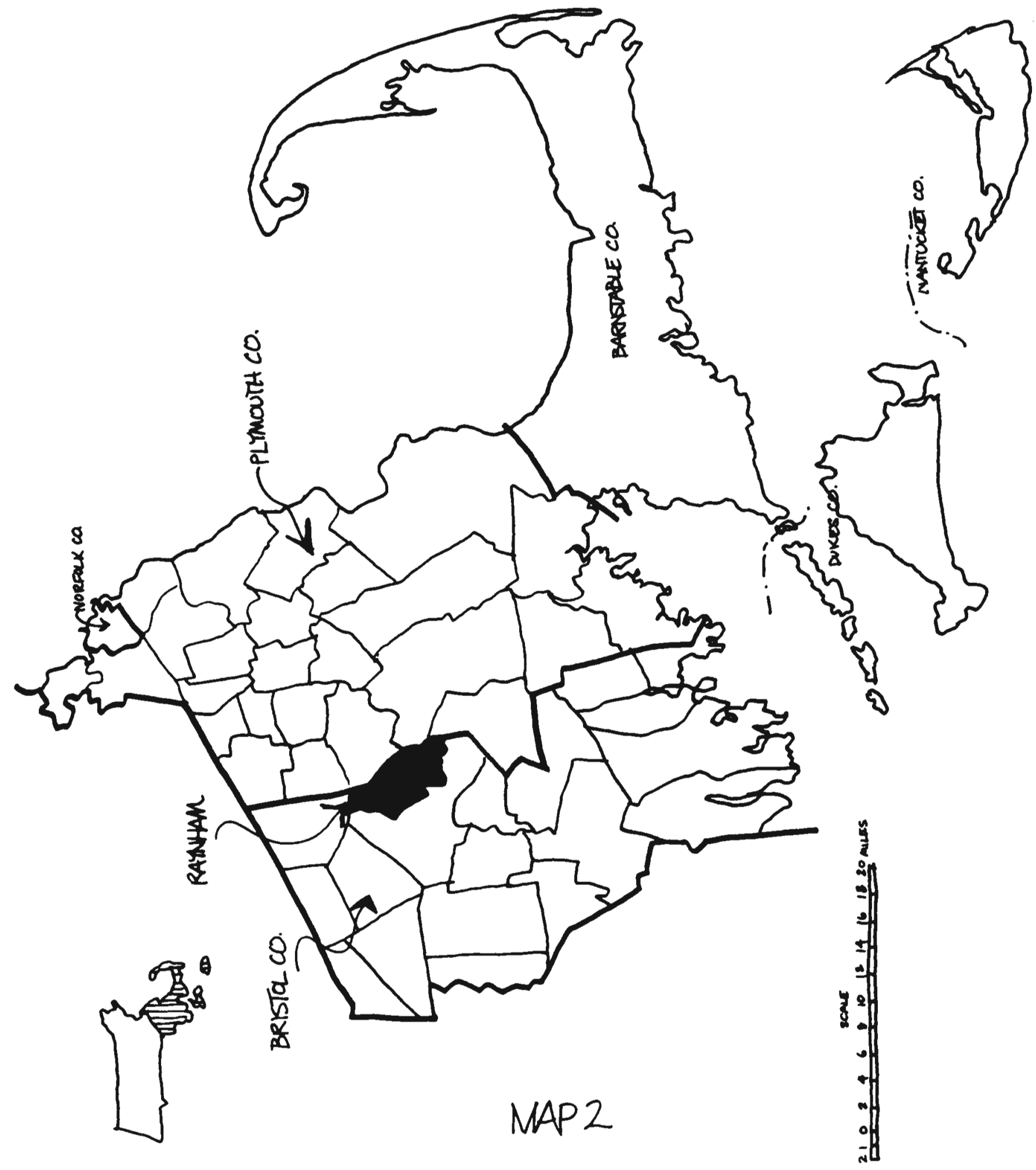


demand for housing. Median home values in Bristol County were $\$ 40,600$ in 1980 and \$44,800 in Plymouth County, and have since climbed much higher. Neither Bristol nor Plymouth County has many condominium units because many individual town' zoning regulations do not permit them. More units will be built in time, but single family homes are still the most desirable form of housing. In fact, in $1980,53.8 \%$ of year round housing units in Bristol County had one unit per address and $74.4 \%$ in Bristol County. These reflect the more urban nature of Bristol County but still show the high percentage of single family homes in the area as a whole.

The occupation of employed workers in 1980 is shown below, by county and combined for southeastern Massachusetts.

Table IIIa

Occupation by County (1980 U.S. Census)

Occupation

Managerial \& Prof. Specialty

Technical, Sales, Admin. Support

Service Occupations

Farming, Forestry, Fishing

Precision Prod., Craft, Repair

Operators, Fabricators, Laborers

\begin{tabular}{lrlll}
\multicolumn{2}{c}{ Bristol } & & \multicolumn{2}{c}{ P1ymouth } \\
\cline { 5 - 6 } 39,301 & $18.5 \%$ & & 44,366 & $25.5 \%$ \\
54,734 & $25.8 \%$ & & 54,693 & $31.1 \%$ \\
26,777 & $12.6 \%$ & & 24,103 & $13.7 \%$ \\
2,656 & $1.3 \%$ & 1,928 & $1.1 \%$ \\
28,192 & $13.3 \%$ & & 23,335 & $13.3 \%$ \\
60,775 & $28.6 \%$ & 27,343 & $15.6 \%$
\end{tabular}


Table IIIb

Occupation by Percent of Residents

$\begin{array}{lccc}\text { Occupation } & \text { S.E. Mass. } & \text { Raynham } \\ \text { Managerial \& Prof. Specialty } & 21.6 \% & 27.2 \%, \\ \text { Technical, Sales, Admin. Support } & 13.1 \% & 13.0 \% \\ \text { Farming, Forestry, Fishing } & 1.2 \% & 1.1 \% \\ \text { Precision Prod., Craft, Repair } & 13.1 \% & 13.8 \% \\ \text { Operators, Fabricators, Laborers } & 22.7 \% & 13.0 \%\end{array}$

Residents of Southeastern Massachusetts are skilled workers, with the majority employed in the fields of Technical, Sales, and Administrative Support positions and to a smaller degree Operators, Fabricators, and Laborers, with the distribution fairly even. Occupations of Raynham residents are typical of the area in most categories, except that there are fewer Operators, Fabricators and Laborers in the town (13\%) than in southeastern Massachusetts as a whole $(22.7 \%)$. This reflects the larger white collar population in the town.

Where residents commute is important to know. It indicates if people live in the area in order to be closer to work or if other factors are involved. Commuting patterns are shown below in Table IV. 
Table IV

Commuting Patterns

Travel Time to Work

\begin{tabular}{cccccc}
\multicolumn{2}{c}{ Bristol } & & \multicolumn{2}{c}{ Plymouth } & Total \\
\cline { 5 - 6 } 39,112 & $19.1 \%$ & 28,011 & $16.4 \%$ & $17.8 \%$ \\
88,481 & $43.2 \%$ & 46,786 & $27.5 \%$ & $36.0 \%$ \\
38,022 & $18.6 \%$ & 28,548 & $16.8 \%$ & $17.7 \%$ \\
22,606 & $11.0 \%$ & 30,919 & $18.1 \%$ & $14.3 \%$ \\
16,624 & $8.1 \%$ & 36,125 & $21.2 \%$ & $14.1 \%$
\end{tabular}

While the majority of southeastern Massachusetts residents travel ten to nineteen minutes to work, $28 \%$ of all workers travel over thirty minutes to work, most from Plymouth County, and probably to Boston. This indicates that many residents have chosen to live in the area not because of convenience to work, but for quality of life. Workers means of transportation is shown below. 
$\underline{\text { Table V }}$

Transportation to Work

$\begin{array}{lccc}\text { Mode of Transportation } & \text { Bristol } & \text { Plymouth } & \text { S.E. Mass. } \\ \text { Private Vehicle } & 183,746 & 153,981 & 89.0 \% \\ \text { Drive Alone } & 136,023 & 117,952 & 75.2 \% \\ \text { Carpool } & 47,723 & 36,029 & 24.8 \% \\ \text { Public Transportation } & 4,925 & 7,792 & 3.4 \% \\ \text { Bus or Streetcar } & 3,648 & 6,650 & 80.9 \% \\ \text { Subway or Elevated Train } & 16 & 848 & 6.8 \% \\ \text { Railroad } & 777 & 153 & 7.3 \% \\ \text { Taxicab } & 484 & 241 & 5.7 \% \\ \text { Bicycle } & 543 & 466 & .3 \% \\ \text { Motorcycle } & 332 & 296 & .2 \% \\ \text { Walked Only } & 14,142 & 6,415 & .5 \% \\ \text { Other } & 1,109 & 921 & 5.4 \% \\ \text { Worked At Home } & 2,403 & 25 & .5 \%\end{array}$

Compared with Table $I$, it is evident that Raynham residents rely more on automobiles for commuting than residents of the area as a whole. Part of this is due to the lack of public transportation to major employment centers from Raynham. The automobile is an integral part of life in southeastern Massachusetts as it has a poor public transportation network. Private buslines are available in some areas along with the commuter rail in parts of Bristol County, and access to the rapid transit line to Boston in Braintree, which is convenient to many Plymouth County commuters. Eighty nine percent of al1 southeastern Massachusetts commuters travel by private automobile, and over $75 \%$ of them travel alone, indicating that highway networks provide the easiest method of commuting. 
This analysis shows the character of southeastern Massachusetts as it currently exists. Past population trends show its growth in the last two decades. It can be assumed that these trends have continued since 1980 to the present time, given the factors involved and general state trends.

\section{Form of Government}

The town of Raynham is governed by a board of three elected part-time selectmen. Different boards and commissions handle various jurisdictional areas. The only full-time employment in the town offices are the Town Clerk's staff and Executive Secretary to the Board of Selectmen.

The Planning Board is a non-partisan elected body. Usually positions are held as long as the member desires to remain. The Board enacts the subdivision control laws, zoning bylaws, and state planning regulations. It does not have zoning enforcement powers, as the Building Inspector functions as the enforcement agent. Proposed bylaw and zoning changes are recommended by the board and voted on at town meetings.

There has never been a formal planning organization other than the Planning Board in Raynham because there has been no need. There is therefore no planning tradition, and there is little planning done today other than zoning regulation. Hired consultants and the Southeastern Regional Planning and Economic Development District (SRPEDD) prepare plans on request, but they are seldom used as viable planning documents, because the outcome never seems to be what the Board requested. The Planning Board mainly acts on zoning change requests and does little planning, which is understandable given the lack of time, tools, and expertise. 
In recent years, however, initiatives have been taken by the Conservation Commission which have succeeded in setting aside land which should not be developed, primarily wetlands. The Commission is a visible agency with defined tools.

SRPEDD has been available for the preparation of plans and other studies since 1969. However, it was not utilized frequently until approximately seven years ago when growth pressures became more apparent. The town pays for SRPEDD's services, and rates are cheaper than those of private consultants.

Residents are generally apathetic toward most issues in town, a major problem than often shows up in lack of quorum for public meetings.

The Selectman form of government usually works effectively in a small town, but it has become increasingly cumbersome and inadequate to deal with the town's current problems. This is illustrated by driving Raynham's streets and surveying land uses. A planning board which meets every two weeks and has some professional expertise but few available tools cannot adequately deal with the types of issues being raised in Raynham today. As a member of the Planning Board for one year, it became apparent to me, and had already been apparent to other members, that its tools are inadequate no matter how well versed in planning practice a member is. It is also difficult for members to be objective when they are also residents concerned with property values. A comprehensive approach in the guise of a full-time planner is one solution. Continuity of land use planning and setting aside areas of town for specific types of development is a need that must be addressed. 


\section{Zoning}

The town has eight zoning classifications: Residential A, Residential B, Residential C, Business, Industrial, Farm and Forest, Wetland, and General Use (See Map 3).

The majority of the town is zoned Residential A, which permits such uses as single family detached homes, institutional uses, certain home occupations, and farms or nurseries. Uses which are permitted by consent of the Board of Appeals are private nonprofit clubs, aviation fields, golf courses, convalescent homes, conversion of an existing one family dwelling to a two family dwelling, and the raising of farm animals.

The Residential B zoning classification allows any use permitted in a Residential A zone plus apartment houses. Apartment houses must not exceed thirty five feet in height or three stories, and the number of units permitted is twelve one bedroom or eight two bedroom per building, with a minimum of five hundred square feet of living space. The land zoned Residential $B$ is located in the far southern end of Raynham near the East Taunton line. There are three apartment complexes out of four, however, which are located elsewhere in town, two in General Use districts and one in a Residential A district. Raynham must construct approximately 150 additional multifamily units to comply with state anti-snob zoning standards and be eligible for certain types of funding. Town officials acknowledge that more is needed, but there is no consensus on where they should be located. Their preference would be to earmark most units for middle income or elderly residents. 


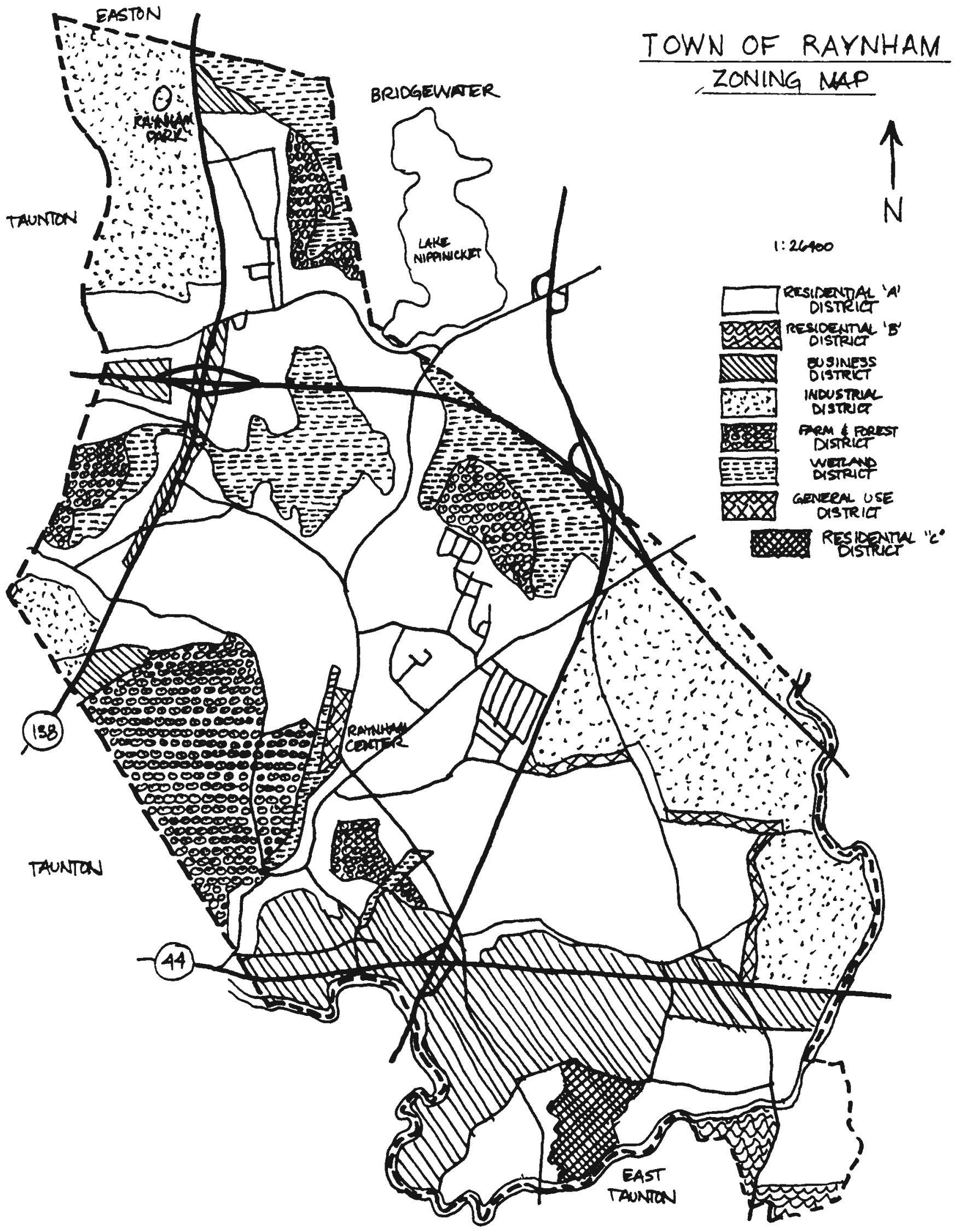


The Residential C zoning classification was instituted in 1984. It allows mobile home parks as well as any use permitted in Residential A zone. One area is currently zoned for this use.

There are approximately 1,350 acres of land zoned for Business, of which about twenty two percent is currently developed. Various uses are permitted in the Business district, including offices, any residential use with the exception of subdivisions, and businesses which do not manufacture goods sold on the same property. Parking requirements stipulate that a business must provide off-street parking equal to twice the floor area of the building. Most Business zoned land is located along Routes 138 and 44, the latter being the most developed for these uses.

Uses permitted in an Industrial district include any business permitted in a Business district, and any manufacturing or industrial use provided that such a use does not provide a detriment to residents and tend to reduce property values. The town has zoned approximately 2,762 acres in this category, but only sixty acres are developed. Much of the land zoned industrial is located in areas of poor soils or wetlands, thus providing a roundabout method for preventing some industrial growth. Because a firm can be denied from locating in such an area, the town feels this insulates them from tremendous industrial growth.

Ten percent of the town land is zoned Farm and Forest, which allows the uses of any religious or educational institution, and any federal, state or local government use, plus those of farm and forest. 
The Wetlands district encompasses nine percent of the towns's acreage and permits agricultural and horticultural uses, and detached one family dwellings with accessory buildings incidential to the growing of timber and crops. Agricultural land must be five acres or more in size and comply with other state standards.

A small amount of land in town is zoned General Use, which is not 1 isted in the zoning bylaws of the town. Although the Planning Board has made a concerted effort to zone all these areas for specific uses, voters have rejected some at town meetings. Any use is permitted in a General Use zone. Site surveys of General Use areas indicate that they contain a bus storage lot, apartment buildings, light industrial uses, and single family residential areas. It appears as that the reason for establishing this district was indecision as to what the best use of the land was, and to accommodate existing uses.

Urban open land uses in the town consist of several government owned parcels, totaling 1,067 acres. Two hundred and eighty five acres are designated conservation land, fifty acres public recreation, 164 acres state owned, 248 acres of mixed use municipal land (recreation, farming, office) at the former Borden Colony mental hosptital, 20 acres of town cemeteries, and 300 acres in the Pine Swamp. The state land in the town consists of a state Forest, Hockamock Swamp Management Area (part of which is zoned industria1), and an Massachusetts Bay Transit Authority right of way preserved by the state for future extension of the proposed Stoughton MBTA rail passenger line from Boston to Cape Cod. 


\section{Footnotes}

1. Caldwe 11 Banker, April 1986

2. Southeastern Regional Planning and Developement District (1981), Comprehensive Growth Policy for Raynham.

3. Ibid. 
CHAPTER 2

The following case studies illustrate and raise some of the major issues that surfaced in the town during my tenure on the Planning Board. Some have been resolved, others have not. In most cases, solutions to these problems are only temporary. The same issues will recur again until manageable solutions and tools are devised to keep them under control.

\section{A. Low and Moderate Income Housing}

In August of 1983, a presentation to the Planning Board outlined the proposal to construct Spruce Woods, a middle income housing development on Warren street in Raynham. Located on six acres of land, the five buildings would contain a total of thirty four to forty units, with rents starting at $\$ 300$ per month, targeted at moderate income families, earning between $\$ 17,000$ and $\$ 25,000$ per year. Through the Farmers Home Administration, developements such as this are targeted at rural communities. Although the developer, Shamray Limited Partnership, referred to the project as "middle income", town officials and residents labeled it low income.

The developer presented the plan to the Planning Board merely as a courtesy. Board approval of plans was not required in this case, as described below. Usual Planning Board action would have been approval or denial of approval of plans depending upon whether it was consistent with zoning and other requirements such as setback.

The land on which the parcel is located was zoned Business with a small Wetlands zone near Dam Lot Brook in the rear of the site. Despite the incompatibility of zoning, the presenters were not seeking a zoning change to Residential B, but a comprehensive permit under Chapter $40 \mathrm{~B}$ of the 
Massachusetts General Laws from the Zoning Board of Appeals. The plan did not conform with apartment house bylaws, and was officially opposed by the Selectmen and Planning Board in their recommendations, stating that the project was inconsistent with local needs and with local land use.

The parcel of 1 and is surrounded by residential uses at the street and business or light industrial uses at the rear. Located less than a half mile north of the commercial strip along Route 44, one of the amenities included a possible sewer tie-in from Richmond Street and convenience to stores, an essential part of FHA quidelines. Another concern was the narrow roads of Richmond Street, Warren Street and South Street, the secondary roads that feed the site from Route 44.

Immediately after the Planning Board meeting when the plan was first disclosed, it made local headlines and quickly became the most controversial issue in town. Unfamiliar with Chapter 40B, some town officials became enraged when they realized that if they denied permission to build the project, the developer could appeal to the state and most likely win his case. This is because Chapter $40 \mathrm{~B}$ states that if a town does not have enough low income housing, the state can grant the comprehensive permit and overrule the town's decision.

Chapter 40B Section 21 explains the process. "Any public agency or limited dividend or non profit organization proposing to build low or moderate income housing may submit to the board of appeals, established under Section 12 of chapter $40 \mathrm{~A}$, a single application to build such housing in lieu of separate applications to the applicable local boards. The board of appeals shall forthwith notify each such local board, as applicable, of the filing of 
such application by sending a copy thereof to such local boards for their recommendations and shall, within 30 days of the receipt of such application, hold a public hearing on the same. The board of appeals shall request the appearance at said hearing of such representatives of said local boards are deemed necessary or helpful in making its decision upon such application and shall have the same power to issue permits or approvals as any local board or official who would otherwise act with respect to such application, including but not limited to the power to attach to said permit or approval conditions and requirements with respect to height, site plan, size or shape, or building materials as are consistent with the terms of this section. The board of appeals, in making its decision on said application, shall take into consideration the recommendations of the local boards and shall have the authority to use the testimony of consultants."(4)

The town officials almost immediately began to determine how many low income housing units there were in the town. One development of approximately 30 subsidized single family homes had been built in the mid 1970's. This is the only low-income housing development in Raynham, and the probable reason for its approval was that the town realized that it had to allow some low cost housing, and single family homes were more in keeping with the character of the town. What the some feared was the "project", densely populated multifamily units with low maintenance standards, which exist in neighboring Taunton, associated with violence and social problems.

Realizing that it did not have enough low-income housing (2.2\%) by state anti-snob zoning standards ( $10 \%)$, some officials wanted to count an elderly housing project and an elderly mobile home park, which would bring the total close to $10 \%$. This was unacceptable, because it assumes that elderly are low 
income and does not fit the state definition of low income housing, namely subsidized units under certain federal and state programs.

At the public hearing, a large turnout of residents was adamantly opposed to the project. All applicable town boards which gave testimony were opposed for various reasons. The Planning Board, for example, was opposed because of the location at the intersection of two narrow streets and noncompatibility with zoning. The Conservation Commission was opposed because of the proximity to Dam Lot Brook and the corresponding Wetlands district. Throughout the whole hearing process, the developer and his representatives asserted that if they were denied a comprehensive permit, they would certainly win their state appeal, as Raynham did not fall within state guidelines for percentage of low and moderate income housing. It was these statements that so angered and frustrated some people in attendance - and the perception that officials could zone the town according to local needs and desires, and the state could supersede this whenever it deemed necessary. This was verbalized some time later in an article in June, 1985. Another developer threatened to build a similar development on a piece of land at the intersection of Routes 138 and 495. A resident questioned how a developer could accomplish this in a Residential A zone, and the Building Inspector responded, "the successful recent appeal of Shamray Limited Partnership to get a comprehensive permit to build 34 units of middle income, subsized housing on Warren street, made it 99 percent certain that a developer would eventually succeed in getting the necessary permits to build 250 units on King's land."(5) The developer wanted to construct a motel/restaurant complex on the site, and is still unresolved.

The Zoning Board of Appeals denied the permit, and the developer appealed to the state. In 1985, the state overruled the town and granted the 
comprehensive permit. The town has subsequently appealed the decision and the outcome is still pending.

\section{B. Cedar Ridge Estates}

One of the ironic things about Cedar Ridge Estates is that after construction, there will be no cedar trees left in the project area. In 1973, the Planning Board approved a subdivision plan called Cedar Ridge Estates for developer Ervin Chickering. Encompassing several acres, the project was never built because the North Raynham Water District had imposed a moratorium on new services.(6) Five single family homes along the existing street were constructed instead. In 1983, Richard Feoderoff had purchased the land from Mr. Chickering, and came before the Planning Board with the identical plan for the subdivision. Since the statute of limitations had expired on the approved plans and town standards such as corner lot size requirements had changed, slight modifications had to be made.

This subdivision plan was typical of those proposed for the town by Mr. Chickering in the 1970 's. Street layouts that disregarded natural features and topography and standard inexpensive split level and ranch homes were typical. One of the busiest developers in Raynham during this time, the landscape of the town is dotted with his straight roads and treeless cul-de-sacs on artificially flattened terrain.

The Cedar Ridge site, located on East Elm Street in north Raynham, consists of woods and swamp located close to Lake Nippinicket (See Map 4 ). Small rolling hills and enormous pine trees characterize the land, with low swampy areas throughout. The land abuts a large parcel owned by the Massachusetts Department of Fisheries and Wildlife on the shores of the lake. 
Possible environmental problems with the site included potential basement flooding and septic tank problems, as there are no sewers in the area. The Conservation Commission had targeted approximately twelve lots in danger areas that should be eliminated.

The subdivision consists of several streets designed with total disregard to natural topography and features such as large old trees and brooks. The plan called for bulldozing and leveling the site, thus destroying all natural amenities including a brook that would be contained in culverts underground. Perhaps the developer has an easier job if he flattens the landscape, but the development would certainly be more attractive if mature trees were left in place. The destruction of topsoil and subsequent erosion were also major environmental issues. Profits for the developer could be increased if the subdivision offered amenities that others did not. However, the demand in Raynham is for moderate cost housing, which these units will satisfy, no matter what the landscaping.

Opposition to the proposal included the abutters. The majority were concerned with the leveling of topography. The homes already built were higher in elevation than plots next to them were to be after excavation. In fact, one abutter owned one half of a man-made steep hill in his backyard, but the plans called for the other half to be excavated. Also, access roads were shown at a lower elevation than an abutter's fence, thereby undermining the fence during construction. The plan had many rough edges because topography and site requirements had changed in the ten years that had passed. However, there was less opposition than is usual for such a large subdivision because abutters knew before moving in that more homes were planned. 
The developer was very conciliatory and unusually generous, meeting with each abutter to reach agreements and compromise on their differences. All came to formal agreements, thus eliminating a part of the opposition. The Planning Board approved the plan after the agreements were made and corrections made to conform with new zoning bylaws, such as increased corner lot size requirements and street width.

The major hurdle was the Conservation Commission and the Massachusetts Department of Environmental Quality Engineering (DEQE), to which the developer appealed for mediation. The DEQE omitted three to four lots, adhering to an Order of Conditions issued to Mr. Chickering years earlier. The Department of Fisheries and Wildife requested that two trees be saved, a white pine and a chestnut, and a representative of the Department offered his opinion that the land would be better suited for cranberry bogs.

The plan was approved, and work on the site began in 1985. However, work was halted when it was discovered that portions of the site were located in two other zoning districts besides Residential A. A portion of the site had been changed to a Farm and Forest zone in 1976, and a portion to General Use at a later date. All have been subsequently changed to Residential A. The oversight occurred because neither the Planning Board, Board of Appeals, Building Inspector, Town Plotter nor developer noticed the changes.(7) But the project did raise questions about Raynham's disappearing woodland and quality of life issues. A large subdivision such as this totally disrupts natural wildife habitats and amenities that make surrounding properties more valuable. 


\section{Mobile Home Parks}

The initiation of a new zoning category for mobile home parks was introduced by George Bumilla, another busy Raynham developer. The owner of a large mobile home park for the elderly, he felt that current zoning was not suitable for the special needs of a mobile home park. In addition, he wanted to expand the current park into a large parcel of land abutting it.

Reactions to the proposal were mixed. The Board of Health (Board of Selectmen) opposed the plan because of the health concerns of densely laid out homes. Rumors at the time speculated that another reason was the fear of blacks and other low income people entering large mobile home parks. Raynham's non-white population grew from 10 in 1970 to 71 in 1980 , only $1 \%$ of its total population.

Residents of the existing park were well organized and attended meetings en masse to vote in favor of the proposal. All testified that life in the park was idyllic, both socially and economically. Other town residents present at the meetings and hearings were generally against the idea of mobile home parks but became sold on the idea of zoning them in one area to prevent proliferation in various locations around town. In addition, many residents were in favor of having a place nearby where parents or grandparents could live when they retired.

The Planning Board recommended the zoning change at a town meeting after the public hearing process had ended. We, too, were sold on the idea of a special zoning category for mobile home parks, like Planned Unit Developments, or other special use classifications. At a special town meeting, the town voted for the Residential C zone and designated one area for the 
classification, the parcel that George Bumilla wished to build upon.

One issue raised during the process was the legality of instituting a new type of zoning district and then specifically zoning one parcel for that land use, a parcel defined by property lines. Of course additional tracts could be zoned in the future, but in Raynham, most zoning changes are proposed by developers for one specific parcel, and are carried out in that manner. This has tended to weaken zoning as a planning tool and raises the issue of spot zoning. 


\section{Footnotes}

4. Massachusetts General Laws, Chapter 40B, Section 21.

5. Taunton Daily Gazette, "Raynham Housing Bid May Be A Threat", June 26, 1985.

6. Ibid., "Question of Zoning Snags Cedar Ridge", Aug. 9, 1985.

7. Ibid. 


\section{CHAPTER 3}

Analysis

The case studies illustrate the different types of issues raised in this growing community. Low cost housing, subdivision controls, design review, zoning, and appropriate land use are typical issues raised in Raynham and other municipalities in southeastern Massachusetts.

Low income housing, something that most people would agree is needed today, is also something that few residents of Raynham want in their "backyard". Through Chapter 40B, the state has mandated that each municipality must share the burden for low income housing. Although most communities do not prohibit such developments, some use other methods to discourage it. Some small towns use the prohibition of and strict standards for apartment houses and other high density developments plus large lot sizes for single family homes. Although Raynham does not use the latter method, it does discourage apartments by zoning little land for this use and by imposing strict regulations as to size and number of units on one site. Some communities, such as adjacent Taunton, complain that they have more low income housing and halfway houses (i.e. undesirable land uses) than its neighbors. While it is true that it does have a larger proportion than the more rural comunities surrounding it, Taunton also has municipal services like sewers, public transportation and health facilities that most small towns do not. But each town should share the burden of low and moderate income housing, and indeed, it seems that the $10 \%$ quota is relatively low. Ten percent low income housing should not severely impact the town's services or property values, if at al1. 
These are commonly the issues raised at public hearings when such proposals are discussed. The fall of property values is important to every homeowner, but perhaps more important to Raynham residents as many are first time homeowners and refugees from Taunton. Their point of view is easy to understand but may not be valid. There is no guarantee that values will not drop, but low income housing does not have to be an eyesore if designed well. The impact on town services of more housing, particularly higher density development, may be adverse in the short run, but service delivery systems can be improved and upgraded. Although this may lead to higher taxes to support the increase, it is important to remember that all communities must share the responsibility for housing middle and low income families.

Water quality is a growing concern in Raynham. The poor quality at one main well in town forces Raynham to occasionally purchase water from the town of Bridgewater. Possible contamination from a nearby gas station has been studied and water purification equipment is now in place. Aquifer protection has also become increasingly important. Until these problems are solved or management tools are developed, future development in the Raynham Center'Water District should be slowed down. Unfortunately, the district encompasses the majority of town including the Route 44 business area and growing neighborhoods in Raynham center.

Sewage problems arise from the lack of sewer lines in the majority of residential areas of town. Soil conditions in some parts of Raynham are not suitable for individual septic systems. However, the expensive installation of sewer lines and the accomodation of treatment plants do not seem feasible or economical for so small a town with scattered population centers. A solution would be to continue expanding existing lines from Taunton, providing 
the city can accommodate the increased loads. Although opponents may cite this as facilitating unwanted growth, at least the certain growth will be environmentally safe and concentrated in such areas. Trends indicate that growth will occur regardless.

Environmental safeguarding is the assigned job of the Conservation Commission. Every new construction project requires the submittal of a Notice of Intent to the Commission. Through public hearing and site evaluation, they determine if environmental effects are adverse. In implementing the National Environmental Policy Act, environmental assessments and impact statements are often required from developers. The Commission has become increasingly bogged down in paperwork and legal matters. Recently, they requested the authority to hire a part-time assistant to help with the workload. Fifteen years ago the main function of the Commission was to mark nature trails and review proposals for construction in wetland areas. Now, due to the increase in state and federal laws designed to protect the environment and the increase in local development, the volunteer Commission has reached the limit at which an assistant must be hired, similar to the Board of Selectmen.

Subdivision controls consist of those regulations set forth in the Massachusetts General Laws, Chapter 40A. Raynham, for the most part, has not developed stricter standards, probably because it has not been necessary. The subdivision controls are limited, as evidenced by Cedar Ridge Estates. The laws are general and limit the Planning Board's action to basically approving or denying approval of plans based on zoning regulations and subdivision requirements. Some control over the developers layout and aesthetic design would be desirable. A design review process where the ability to exact additional aesthetic considerations could be helpful in assuring that the 
character of the town remains consistent with residents wishes. Such a review process could have improved Cedar Ridge's appearance by retaining mature vegetation and landforms but not sacrificing low housing costs.

Raynham has a new, vaguely worded "buffer zone" bylaw that is an attempt to insulate residential areas from inconsistent land uses. A strip of land (no less than fifty feet) is required between new business use in any zoning district and a residential use or zone. There has been some controversy over this, residents complaining that it is not extensive enough, and developers complaining that they are being deprived the use of their land. Unfortunately, the bylaw was copied from another town and implemented without Planning Board members or residents having a clear understanding of it. It was mainly enacted due to pressure from a group of residents who were impacted by conflicting zoning districts adjacent to each other.

Attitudes toward design review and aesthetic considerations may be more widely accepted in the town than in the past. One reason is that the town is visibly growing, and development where environmental sensitivity is not present are far more noticeable. Residents seem to be more concerned with environmental protection as well, because of increased growth pressures, and the general consciousness-raising in related fields. Once a town with large wooded areas, Raynham is now realizing that these areas are rapidly shrinking.

Zoning is used in Raynham as the major planning tool. For most towns, zoning does not solve perceived problems; unless the town or rural area is experiencing development pressures, land use is probably not a major problem. (8) However, in Raynham, land use is a major problem. Zoning as a planning tool in rural areas can be used more effectively than is currently being done in Raynham. 
The most common phrase used in Planning Board meetings is that you don't want to deprive anyone the use of his land. This is one parameter of zoning methodology, but Raynham is not flexible in finding valid reasons for limiting the use of one's land. For instance, a person with a piece of property on Route 138 zoned Residential A could propose a car dealership on the site and institute a request for zoning change or variance. A petition signed by ten registered voters is sufficient to bring a change to the Planning Board, and variances are decided by the Board of Appeals. A residential neighbor could oppose the project, but more often than not, when the proposal would come before either board, they would usually recommend or approve the zoning change. The Planning Board usually agrees with the developer and recommends the change to a town meeting where it is voted upon. The developer usually claimed that the owner of the site was being denied the economic potential of his land in a prime business area and would increase the tax base. Unfortunately, scenarios like this occur often with regard to Route 138. A resident stated at a town meeting in November, 1985, that "Route 138 is not a Route 44. Let's look seriously at how we want our community developed before we jump on the development bandwagon."(9) Such zoning actions have undermined the zoning that originally set aside areas supposedly suitable to each type of land use.

The manner in which Raynham was zoned in the first place, however, makes this difficult. When zoning bylaws were first enacted, one member of the Planning Board took it upon himself to zone the town. After he had zoned the town business, residential, industrial, etc., he presented it to the town. Approved at town meeting, apparently few understood why certain areas were zoned for specific uses. It is this lack of understanding why certain 
districts exist where they do and the lack of a conceptual framework upon which to build and modify over time that permits such easy zoning change. Since this is virtually the only planning tool used by the planners, they cannot be effective and strong enough as a body in land use planning.

In the case of the new Residential C zone, a developer drew up an ordinance and presented it to the Planning Board. The Board modified it a little bit, recommended it to the town, had it approved, then zoned his parcel of land for that use. If anyone had raised the spot zoning issue, it would have been valid.

Certain areas of the town, namely along Route 138, are still gray areas where it has never been decided whether it is more suitable for business or residential development. Historically, there were pockets of small businesses between long stretches of residential homes. After the completion of Route 495, which intersects the busy state highway, commercial development pressures along this road have intensified. Proposals such as a major hotel, medical center, low income housing, as well as smaller businesses such as banks, mini-shopping plazas and restaurants have either been discussed, threatened, or approved, further disrupting the residential nature of the street. The road has historically been a busy one, especially during the summer when Raynham Park (greyhound racing) was open. Now it is open year round, adding additional traffic to the increased traffic from Route 495. Traffic signals will have to be installed in the future as accidents become more frequent. Although businesses located on Route 138 have never been successful historically, entrepreneurs apparently feel differently now. The disposition of this area should be decided soon. SRPEDD proposed a mix of residential and commercial development in 1981. This is probably the most prudent approach, 
keeping residential areas intact but zoning pockets suitable for business for that use.

The idea that traffic and environmental constraints will inevitably slow development is not valid in Raynham at the present time. Route 44 has grown so rapidly without regard to traffic flow, that the two lane section of the road between the Taunton line and Route 24 (called the "Golden Mile") (See Map 5) experiences gridlock on Saturdays and during rush hour. Shopping plazas and fast food restaurants abound. At least sewer lines are available, indeed without them, such extensive development may not have been possible. A new proposal to extend the sewer Iine across Route 24 is expected to be approved by the state sometime in 1986. The Planning Board has already been approached by developers proposing an industrial park, a shopping center and a hazardous waste collection center on a large parcel of business zoned land just across Route 24. The hazardous waste facility has since been located elsewhere after fervent opposition. The town now bans such activity.

An analysis of Raynham's growth, factors that influence it, and issues raised because of it indicates that a solution, or at least management tools are needed. Current growth will continue into the future in the same patterns unless controls are exercised that influence appropriate land uses. Selectman Donald Francis stated in November, 1985, "We have never had it clear-cut put to us whether we want to stay a bedroom community or we want to discourage business, although many times we've seen business discouraged."(10) The selectmen and other town officials should not wait for a clear voice from constituents - they should make some decisions soon or it will be too late. 


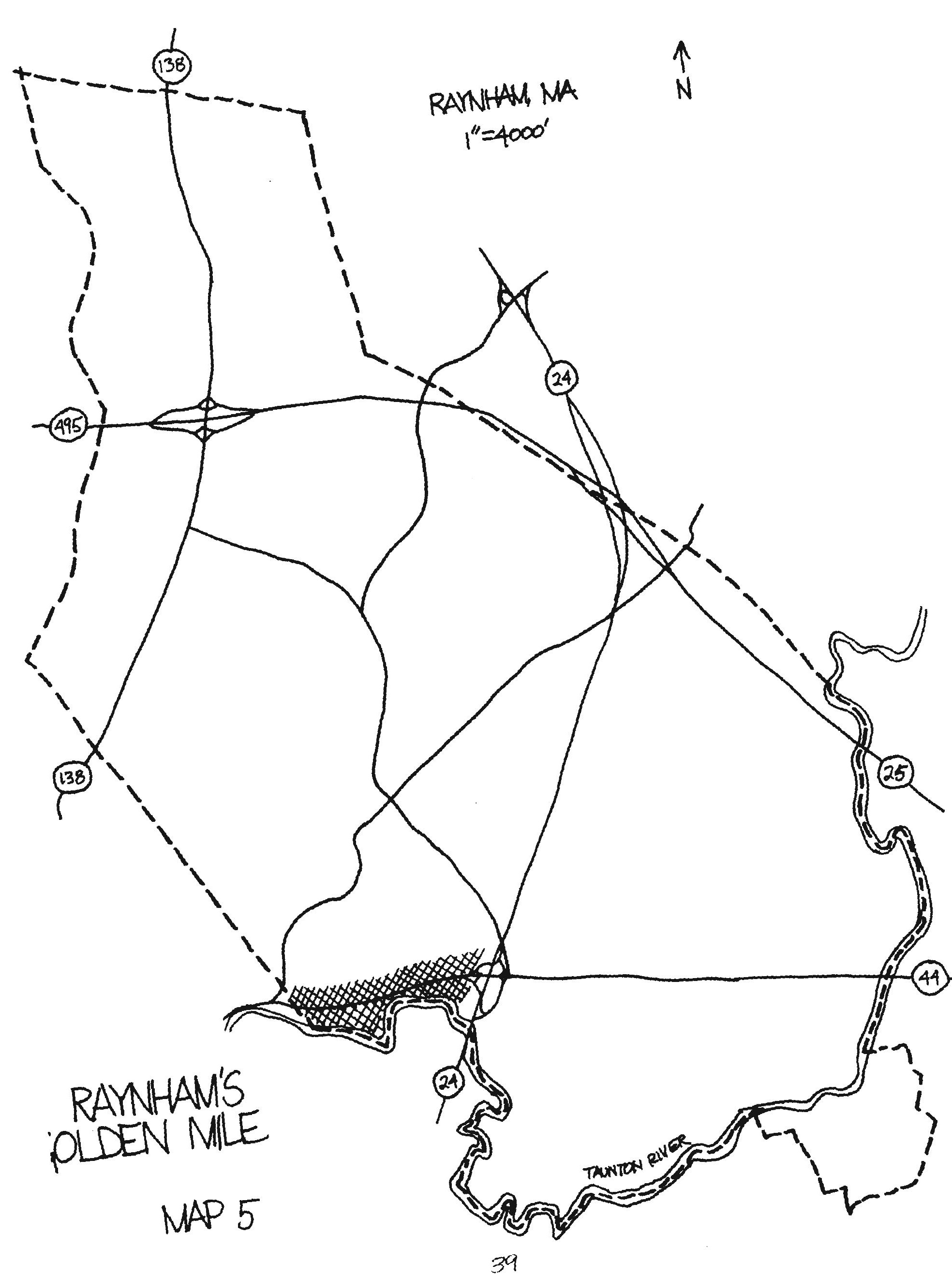


8. Judith Getsels and Charles Thurow, (1979), Rural and Small Town Planning, (Planners Press, Chicago, IL), p. 53

9. Taunton Daily Gazette, "Voters Unhappy With Zoning Presentation" Nov. 19,1985 .

10. Ibid., "Voter Tally is Problem for Raynham Rezoning", Nov. 20, 1985. 


\section{CHAPTER 4}

Recommendations and Conclusion

Recent dynamics in Raynham indicate that events may, in the near future, reach a point where the current governmental organization cannot handle the pressures. A coordinated approach to zoning, land use control and managing growth cannot occur unless a qualified professional undertakes these tasks. The Planning Board, Zoning Board of Appeals and Selectmen have all done a good job in the past, but as pressures mount additional help will be needed. Zoning has been haphazard, an outcome of the town's philosophy that it is wrong to deprive anyone the use of his land. The philosphy is also held by most residents. For this reason, a coordinated approach to land use planning is lacking. In addition, since all zone changes are subject to town meeting vote, it is difficult to pass items that are controversial. Although Planning Board members are knowledgable about the town, desires of the residents, and laws and regulations, the town's future needs serious consideration. If growth controls are implemented by a qualified professional on a full-time basis, the town can emerge from its crisis intact.

Therefore, I think it is time that the town create a position and hire a full-time planner, preferably with experience in suburban planning and growth management. Residents and town officials should be prepared to "bite the bullet" and endure a difficult period. This may be unrealistic, and although it won't be easy, it can be accomplished. Approval of zoning changes should still be subject to town vote, however. The planner's job would be to provide a coordinated approach to growth and capital planning and act as a technical 
advisor. The Planning Board role would remain the same - it would still approve or deny plans and remain a public forum.

Another recommendation involves the investigation of replacing specification zones with performance codes. Getzels and Thurow state that "the history of zoning and land regulations has demonstrated a slow but steady movement toward replacing specification zones with performance codes. Such techniques as planned unit development, floating zones, special use permits, and industrial performance zoning have all been attempts to regulate a particular use or activity on the basis of its performance. These techniques have added flexibility or discretion to traditional zoning by establishing a list of criteria by which development proposals will be reviewed on a case-by-case basis, rather than predetermining what will or will not be allowed."(11) In such a system, areas where growth could occur in the future, for example along stretches of Route 138, existing zones could be replaced by a permit system. Instead, there are no uses by right in the areas except the existing ones and a few prohibited ones. Getzels and Thurow cite an example used in the town of Farmington, Maine. Their simple permit system prohibits "adverse effects" from land use change. The ordinance states that land use changes having an adverse effect on the character of the surrounding areas are prohibited, and Planning Board approval is required. Land use is defined as altering the use of a property from one category of use to another. The surrounding area is defined as property within 500 feet of the proposed development. A builder can conform to the existing uses or obtain a permit.(12) If Raynham were to undertake such a form of control, stricter requirements defining adverse effects would have to be defined. The Planning Board, Selectmen, and full-time planner would have to be involved in the permit granting process. 
Performance standards seem to be a better alternative to the rather flexible one described above. These involve a thorough analysis of the effects of a proposed development on the town's water supply, sewage system, fire protection, and environmental protection. It stipulates where specific types of uses should be located, such as commercial and industrial areas. Any variance from the plan would be subject to strict scrutiny.

This would provide an added dimension to the current zoning system. Presently, effects on the water supply, sewage system, and evironmental protection are only given a cursory discussion. A developer will state that impacts are minimal and the water district management is not routinely consulted in matters of individual homes, and even then is only asked an opinion. The Conservation Commission is only consulted in matters where infringement on possible wetlands or other protected areas are proposed. Therefore, a system where possible effects were documented and discussed at length may be what the town needs. It would involve few changes in government organizational structure. By specifying where certain uses may be located, the town can decide what land uses belong where. Performance standards will help insure that effects on the environment and town services are thoroughly investigated.

Many rural and suburban towns are now encountering development problems similar to Raynham's. The town is not alone, as several of the surrounding towns are dealing with the same problems. In Bridgewater, where zoning is strictly adhered to and zoning and land use changes are scrutinized, growth has been better controlled. The town of Middleboro has discussed hiring a full-time planner, and has tried to attract industry to its industrial parks. In these towns, specification codes seem to work well. In Raynham, where the 
methodology is unclear, the designation of appropriate land uses has not succeeded. If performance codes were enacted and were understood, the town's chances of successfully handling growth would improve.

The housing issue is the most pressing one in Raynham today. As real estate prices climb, there will be more low and moderate income housing needed. Opposition voiced by residents wanting to maintain their neighborhood status quo will not go away. "The saying, 'A man's home is his castle', implies that each man has the right to exclude anyone from his home. Exercising this power does not mean placing the property rights of the occupant over the personal rights of those seeking entry."(13) Fears of rising crime, vandalism, taxes, and lowered property values must be dealt with. However, in Raynham, I see little hope of this in the near future. It will happen gradually over time. As more low and moderate income people enter the town, and they will, they will form linkages with those already there. Eventually the community will exhibit an improved quality of 1 ife, because quality of life is linked to bonds formed with neighbors. I believe this will happen in Raynham, as it did in the $1960^{\prime} \mathrm{s}$ when an influx of new residents caused tensions to rise among older residents. In time, bonds were formed and the community became less divided.

The process of forming linkages is easier when types of housing are compatible. It would be easier for neighbors of Spruce Woods to know their new neighbors if the housing was compatible. The apartment house solution for low and moderate income families among single family residences does not facilitate the formation of bonds. Since they would be less likely to meet during yardwork, for example, the only avenue left will be in a social context. Churches and schools provide such a forum. Perhaps an alternative 
would be townhouse development which is more compatible with surrounding structures. If the town took the initiative and encouraged developers to build compatible low income housing, the results would be better than having various projects forced on them. However, the difficult procedure whereby Spruce Woods was turned down by the Board of Appeals will happen again. I think the town realizes by now, though, that they will have to accommodate low and moderate income housing in the future.

Design review procedures for subdivisions, and indeed for all development, could be instituted in Raynham. These, coupled with environmental review, a full-time planner, and a relaxed attitude toward low income housing would set Raynham on the right track toward controlling its inevitable growth. However, I don't realistically see all these happening in the near future. Design review procedures, environmental review and relaxed attitudes toward accomodating the poor are all in the future. The town seems headed in this direction already. A general distrust of town government may hinder the hiring of a planner for a number of years. It would be difficult to replace specification with performance codes or strengthen planning tools without a planner on board. I think that Raynham will be burned badly for not handling growth in a clear-cut systematic manner unless key decision makers take a stand and assume control.

For my part, I am glad that I spent the time on the Planning Board. I only hope that this interesting town can live up to its potential and develop into the community with a high quality of life that it imagines it is. 


\section{Footnotes}

11. Judith Getzels and Charles Thurow (1979), Rural and Sma11 Town Planning, (Planners Press, Chicago, IL), p.90.

12. Ibid., p.90.

13. Anthony Downs (1973), Opening Up the Suburbs, (The Colonial Press, Clinton, MA), p.65. 


\section{BIBLIOGRAPHY}

Annual Report of the -Town Officers of the Town of Raynham, 1981, 1984, 1985.

Commerce Park Corporation, Commerce Park at Middleboro Circle, 1981.

Downe C. and Wells P., Consultants, Open Space and Passive Recreation Plan, 1977.

Downs A., Opening Up the Suburbs, The Colonial Press, Clinton, MA, 1973.

Getzels J. and Thurow C., Rural and Sma11 Town Planning, The Planners Press, Chicago, IL, 1979.

Haar C.M. and Iatridis D.S., Housing the Poor in Suburbia, Ballinger Publishing Company, Cambridge, MA, 1974.

Massachusetts Executive Office of Communities and Development, Municipal Planning and Subdivision Legislation, 1983.

Massachusetts Executive Office of Communities and Development, The Zoning Act, 1983.

Southeastern Regional Planning and Economic Development District, Comprehensive Growth Policy Plan for Raynham, 1981.

Southeastern Regional Planning and Economic Development District, Southeastern Massachusetts Fact Book, 1982.

Town of Raynham Procedure By-Laws and Zoning By-Laws, 1983.

U.S. Census Bureau, U.S. Census of Population and Housing, 1970, 1980. 